\title{
Happy New 2008: From Mild Cognitive Impairment to Pleasure Circuitry
}

\author{
By Eric Hollander, MD
}

January brings a start to 2008, and allows us to briefly reflect where we are coming from, and where we are heading in the new year.

This month, CNS Spectrums brings us another installment of "Brain Regions of Interest." This series, edited by Michael Trimble, MD, FRCP, FRPsych, allows us to describe the neuroanatomy and the functional network links of specific brain regions and their connecting integrated circuits. This is of great use to both clinicians and clinical neuroscientists. Daniel S. Zahm, PhD, describes both the pleasure circuits of the brain as well as the processes involved in fear conditioning that are mediated by basal forebrain macrosystems and dopamine projections. This system mediates not only contextual fear but also appetitive drives, such as interest, initiative, and motivation to pursue goals.

This new "Brain Regions of Interest" series adds to the existing outstanding clinical columns from Stephen M. Stahl, MD, PhD, and Dan $J$. Stein, MD, PhD, that enliven the pages of the journal, increase our expertise in psychopharmacology, and highlight case series of functional imaging. In the new year, we also await new columns on novel imaging techniques, and new brain-stimulation techniques, designed to provide a practical update of cutting-edge methods for the clinical neurosciences. Please provide us your feedback on these columns via communiques.

The theme of this months issue is mild cognitive impairment (MCl). James $\mathrm{M}$. Ellison, MD, $\mathrm{MPH}$, and colleagues posit that while the presence of noncognitive behavioral symptoms is not required for a diagnosis of $\mathrm{MCl}$, these symptoms are frequently present and constitute an important source of morbidity.

Apathy and depression may be difficult to differentiate, and targeted treatment of depression may fail to address apathy. Aaron P. Nelson, PhD, and Margaret $\mathrm{O}^{\prime}$ Connor, $\mathrm{PhD}$, suggest that for most patients, $\mathrm{MCl}$ represents a transitional state between normal ageing and mild dementia, with multiple subtypes and involvement of symptoms of other cognitive domains, such as executive function, language, and visuospatial dysfunction. As we move closer to disease-modifying therapy for Alzheimer's disease, early identification is becoming even more critical for identifying patients who have an opportunity to benefit from treatment.

Ronald C. Petersen, MD, PhD, and Selamawit Negash, PhD, present an algorithm to assist clinicians in subclassifying various types of $\mathrm{MCl}$, and discusses specific progression factors including genetic, neuroimaging, biomarker, and clinical characteristics.

Charles L. Bowden, MD, and colleagues assess the tolerability of and efficacy with lamotrigine (LTG) administered concomitantly with commonly prescribed bipolar medications. The percentages of patients with any reported adverse event and reported adverse events of mood symptoms or rash were comparable between those taking LTG with or without other concomitant bipolar medications. Adverse events in $>10 \%$ of patients in at least one subgroup were headache, infection, nausea, rash, influenza, diarrhea, dizziness, and somnolence. Baseline scores on psychiatric rating scales improved similarly with LTG co-administered with other bipolar medications, and the pattern of results did not differ by baseline polarity of mood symptoms. Therefore, LTG co-administered with valproate, lithium, an atypical antipsychotic, or a selective serotonin reuptake inhibitor in the treatment of bipolar disorder seemed to be well tolerated and was associated with clinical improvement.

In addition, two communiques address pica and novel neuropeptides. Alan Jay Lerner, MD, describes the case of a woman with autism, 
severe mental retardation, and seizures, who had severe and persistent pica associated with features of frontal disinhibition. In this case, the pica was markedly reduced with the atypical antipsychotic agent olanzapine. Chi-Un Pae, MD, discusses some preliminary thoughts about a novel neuropeptide "Semax" that increases brain-derived neurotrophic factor and, as such, could potentially have effects of hippocampal neuroplasticity and perhaps mood and attention. Of course, controlled studies would be needed to determine whether these hypothesized effects indeed are influenced by this neuropeptide.

Finally, I would like to thank the excellent and hard work of our peer reviewers, without whom we could not maintain the high standards of the journal. I would also like to thank our excellent columnists Dr. Stahl, Dr. Stein, and Dr. Trimble who have enriched the scientific diversity of the publication as well as the authors whose work contributed to the rising impact factor of the journal. Last but not least, I would like to thank the avid readers of the journal, and urge them to continue to provide indepth feedback about what they read in the journal, what they would like to see more of, and to continue to submit communiques.

May 2008 be healthy, prosperous, and full of new insights. CNS

\section{We would like to thank the following peer reviewers who contributed to CNS Spectrums in 2007:}

Jon S. Abramowitz, PhD, ABPP

Caleb Adler, MD

Andrea Allen, PhD

R.H. Belmaker, MD

Gulcin Benbir, MD

Gregor E. Berger, MD

Giuseppe Bersani, MD

Carlos Blanco, MD, PhD

Floyd Bloom, MD

Derek Bolton, PhD

Adam Boxer, MD, PhD

David Brent, MO

Ulrike Buhlmann, PhD

Beatriz Camarena, MSc

Franca Centorrino, MD

Samuel R. Chamberlain, PhD

Sherry Chou, MD

Dennis Combs, PhD

Aristides Volpato Cordioli, PhD

H. Branch Coslett, MD

John F. Curry, PhD

Sander Daselaar, PhO

Jonathan Davidson, MD

Burl Daviss, MD

Dev Devanand, MD

Daniel Dickstein, MD

S. Donovan, MD

Hannelore Ehrenreich, MD

Graham Emslie, MD

Andrew Evans, FRACP

Naomi Fineberg, MA, MBBS, MRCPsych

Timothy W. Fong, MD

Leonardo F. Fontenelle, MD, PhD

Sophia Frangou, MD, PhD

Thomas W. Frazier, PhD

Oliver Freudenreich, MD

Rene Garcia, MD

Bradley N. Gaynes, MD, MPH

Barbara Geller, MD

Daniel A. Geller, MD

Elbert Geuze, PhD
S. Nassir Ghaemi, MD, MPH

Habibollah Ghassemzadeh, PhD

David L. Ginsberg, MD

Rachel Glick, MD

Marco A. Grados, MD, MPH

Jon E. Grant, MD

Robert Grossman, MD

Catherine J. Harmer, DPhil

Kenneth M. Heilman, MD

Haggai Hermesh, MD

Andrew Holmes, PhD

Kurt A. Jellinger, MD

Laurence Jerome, MBChB

Ricardo Jorge, $M D$

Betsy D. Kennard, PsyD

Elias Khawam, MD

Suck Won Kim, MD

Ehud Klein, MD

Anat Brunstein Klomek, PhD

Christopher J. Kratochvil, MD

Loius Lemieux, PhD, MInstP

Giuseppe Mania, MD

Karl Marlowe, MBChB(MD), MSc, PgDCBT,

MRCPsych

Daniel F. Maixner, MD

David Mataix-Cols, PhD

Theo Manschreck, MD

Joseph P. McEvoy, MD

Euripedes Miguel, MD, PhD

Anna K. Morin, PharmD

Jonathan E. Morris, MD, MPH

David J. Muzina, MD

Karyn M. Myers, PhD

Gerald Nestadt, MD, MPH

Thanh Nguyen, MD, FRCP(C)

Darin T. Okuda, MD

Josef Parvizi, MD, PhD

Pal Patcher, MD, PhD, FAPS, FAHA

Eric Peselow, MD

Katharine Phillips, MD

Giuseppe Plazzi, MD
Harrison G. Pope, Jr, MD

Gil Rabinovici, MD

Hannah Reese, MA

Luis Augusto Rohde, MD, DSc

Hanna Rosenmann, PhD

Barbara Olasov Rothbaum, PhD, ABPP

Peter Roy-Byrne, MD

Steven Samples, MD

Jack Samuels, PhD

Clifford B. Saper, MD, PhD

Jitender Sareen, MD, FRCPC

Soraya Seedat, MBChB, FCPsych, MMed

(Psych), PhD

Alessandro Serretti, MD

Jerome M. Siegel, PhD

George Simpson, MD

Nathan Andrew Shapira, MD, PhD

Ward T. Smith, MD

Makoto Sohmiya, MD, PhD

Serena Spudich, MD

Mark Stacy, MD

Alessandro Stefani, MD

Daniel Stewart, MD

Eric A. Storch, PhD

Elsdon Storey, MBBS, DPhil, FRACP

Alan C. Swann, MD

Albina Rodrigues Torres, MD, PhD

Maarten Uyttenboogaart, MD

David Veale, MD, FRCPsych

Karen Dineen Wagner, MD, PhD

Glenn Waller, BA, MClin Psychology, DPhil

Richard Weisler, MD

Myrna M. Weissman, PhD

Abraham Weixman, MD

Thomas Wise, MD

Kevin D. Wu, PhD

Yanki Yazgan, MD

Ruth P. Zager, MD

Nathan Zasler, MD

Alexander Zubkov, MD, PhD 